\title{
Tropospheric influence on dropped calls in mobile networks
}

\author{
Bassey Jeremiah Ekah ${ }^{1,}{ }^{*}$, Joel Iloke ${ }^{2}$ and Ukoette Jeremiah Ekah ${ }^{2}$ \\ 1 Department of Physics, University of Calabar, Nigeria. \\ 2 Department of Physics, Cross River University of Technology, Nigeria.
}

Global Journal of Engineering and Technology Advances, 2022, 10(02), 083-093

Publication history: Received on 20 January 2022; revised on 24 February 2022; accepted on 26 February 2022

Article DOI: https://doi.org/10.30574/gjeta.2022.10.2.0039

\begin{abstract}
It is common knowledge that tropospheric variables affect signals, thereby distorting coverage. Since the major factor affecting dropped calls is coverage and the penetration depth of the signal strength transmitted by a wireless system determines its coverage, therefore, there is a tendency for tropospheric variables to affect dropped calls. This research investigates the effects of relative humidity, wind speed, rainfall and temperature on dropped calls for four mobile networks (MTN, Airtel, Globacom and 9mobile) in Cross River State, Nigeria. Six years data of weather variables collected from the Nigerian Meteorological Agency (NiMet), Cross River State and six years Drop Call Rate (DCR) data obtained from the telecommunications regulatory body, Nigerian Communication Commission (NCC), was used for this study, both spanning from January 2015 to December 2020. From the collected data, graphs were plotted and, in each case, the DCR of the mobile networks were the dependent variables while the tropospheric variables were the independent variables. Also, regression models were obtained to forecast the DCR of each network, provided the tropospheric variable at each given period is known. Finally, the variables were correlated to give a picture of how each tropospheric variable related to the DCR of the mobile networks. For MTN and 9mobile networks, a low positive correlation was obtained for rainfall and relative humidity, a highly positive correlation was obtained for wind speed while a lowly negative correlation was obtained for temperature. For Airtel network, a moderately negative correlation exists between DCR and relative humidity/temperature while a low positive relationship existed for rainfall. However, a low negative relationship was observed for wind speed. For Globacom network, a moderately negative and a moderately positive relationship was obtained for rainfall and relative humidity respectively while a highly positive and a lowly negative correlation was obtained for temperature/wind speed against DCR. This result will be very useful to the meteorologist, mobile network planners and the network operators.
\end{abstract}

Keywords: Drop Calls; Drop Call Rate; Tropospheric Variables; Mobile Networks; Service Retainability; Quality of Service

\section{Introduction}

The increasing poor Quality of Service (QoS) rendered by telecommunication operators in Nigeria is worrisome and frustrating. Cellular network subscribers' resort to purchasing Subscribers Identity Module (SIM) cards of all existing cellular network operators, as one cannot predict when one will obtain good QoS from any of the telecommunication operators. To judge mobile network QoS, regulatory authorities and telecommunication operators, use Key Performance Indicators (KPIs), which hinges on the end user's perspective [1]. These KPIs are classified into service reliability [2], service integrity [3], service accessibility, service mobility and service retainability [4].

One major KPI investigated under service retainability is the drop call. A drop call is a call that aborts prematurely before being released normally by either the caller or called party. That is, the call is dropped before the exchange of Released

\footnotetext{
${ }^{*}$ Corresponding author: Bassey Jeremiah Ekah

Department of Physics, University of Calabar, Nigeria.

Copyright (C) 2022 Author(s) retain the copyright of this article. This article is published under the terms of the Creative Commons Attribution Liscense 4.0.
} 
Message "RL_M" and Released Complete Message "RLC_M" in the signaling flow. An appraisal of the aggregate of dropped calls is termed the Drop Call Rate (DCR), which is the amount of dropped calls divided by the sum total of call attempts [5]. Dropped calls are effectuated by degraded signal quality around the precincts of a mobile phone [6], instability in received signal strength [7] and coverage [8].

Telecommunication providers deploy voice services using radio signals and the network is dispersed over large areas known as cells. Each cell has a minimum of a fixed location transceiver, usually called a base station. These transceivers furnish the cells with the network coverage usually relied upon for voice transmission. To ensure good QoS and to outmanoeuvre interference, distinct set of frequencies from the neighbouring cells are used for signal propagation [9]. This cellular network provides signal strength to a mobile phone and these strengths fluctuate with weather [10].

Varying weather conditions affect major KPIs such as service accessibility and retain ability and this causes drastic degradation in system performance [11], leading to lack of coverage, distortion in link quality and therefore, poor QoS [12-13]. In order to achieve good QoS, minimal fluctuations in signal is required to avert higher rate of dropped calls [10]. Therefore, it is essential to explore the factors affecting radio link quality in order to attenuate their influence [14].

The technical factors affecting the QoS of mobile networks have been investigated [15-18]. The effect of tropospheric parameters on telecommunication signals have also been studied [19-24] and its impact has been analyzed [25-42]. Since the knowledge of atmospheric characteristics for service retainability is necessary, the International Telecommunication Union Radio Communications (ITUR) maintains a database for atmospheric characteristics around the world and this is used to estimate weather attenuations and other parameters [35].

From the available literature, no work has been done on the effect of tropospheric variables on mobile network KPIs, except on received signal strength. Again, we deduced that the received signal strength of a cellular system, defines the network penetration level and therefore, its coverage [43-44]. Studies further reveal that voice services of the cellular system depends on network coverage. Since the major factor affecting drop calls is coverage and the penetration depth of the signal strength transmitted by a wireless system determines its coverage, therefore, there is a tendency for tropospheric variables to have effects on drop calls.

It is therefore indispensable to traverse the innumerable factors influencing the link quality in cellular communication systems in order to take the necessary measures and adaptation options to alleviating and controlling its effects. In this study, we are looking into drop calls and how it is affected by four tropospheric variables; wind speed, temperature, relative humidity and rainfall.

\section{Material and methods}

This work investigates how relative humidity, wind speed, rainfall and temperature affect dropped calls in mobile networks. Four mobile networks are investigated in this study; they are MTN network, 9mobile network, Glo network and Airtel network.

The research is carried out in Cross River State, Nigeria. 72 months radiosonde data for Cross River State, obtained from the Nigerian Meteorological Agency (NiMet), is used for this study. These data contain monthly tropospheric data that spans from January 2015 to December 2020.

Furthermore, drop calls data measured through sophisticated counters embedded in the base stations of mobile networks in Cross River State were obtained from the Nigerian Communication Commission. These data spans from January 2015 to December 2020.

The obtained tropospheric and DCR data were then subjected to statistical analyses to obtain a relationship between both variables. A correlation analysis was done to obtain the degree of relationship between the variables investigated while a regression analysis was done to establish a relationship between the variables investigated, as well as to enable us predict and forecast when to expect drop calls or not.

\section{Results and discussion}

This section is divided into four parts. We shall first analyze the effect of relative humidity on call setup for the four networks, followed by the effect of wind speed, rainfall and finally, temperature. 


\subsection{Effects of Relative Humidity on Drop Calls}

In this part, figure 1 shows a graph of DCR against relative humidity plotted for MTN network. A weak positive correlation value of 0.11 was obtained. A regression model to predict possible call setup was obtained as $\mathrm{D}=0.01 \mathrm{R}-$ 0.34 for MTN users. A graph of DCR against relative humidity for Airtel network was revealed in figure 2 . A moderately negative correlation value of -0.55 was developed with a regression model $D=-0.02 R+2.25$ for Airtel users to forecast when it is accurate to make calls. Figure 3 sets forth a graph of DCR against relative humidity for Globacom network. A regression equation, $\mathrm{D}=0.17 \mathrm{R}-13.40$ and a moderately positive correlation value, 0.34 were obtained. A graph of $\mathrm{DCR}$ against relative humidity for 9 mobile network is presented in figure 4 , with a weak positive correlation value of 0.28 and regression equation of $\mathrm{D}=0.03 \mathrm{R}-1.70$. In each regression model developed, $\mathrm{D}$ depicts DCR while $\mathrm{R}$ stands for relative humidity. Therefore, at a known value of relative humidity, it is possible to predict the probability of having dropped calls.

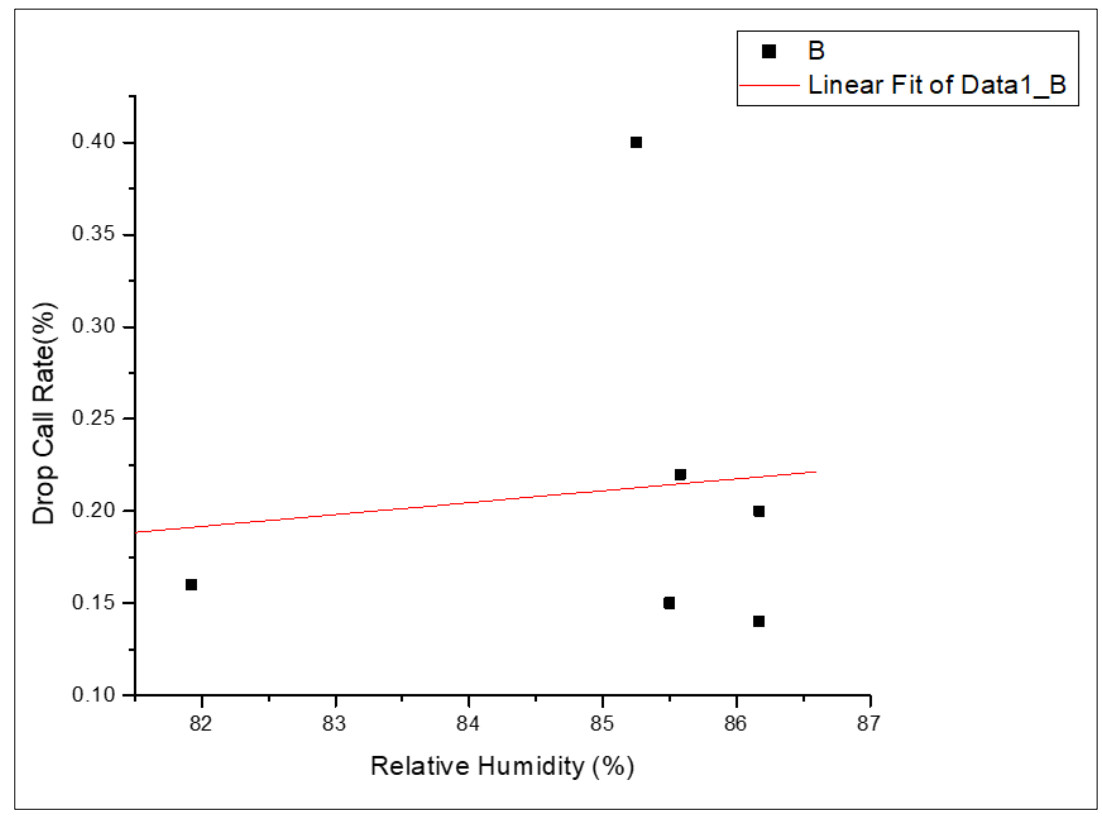

Figure 1 Graph of DCR against Relative Humidity for MTN Network

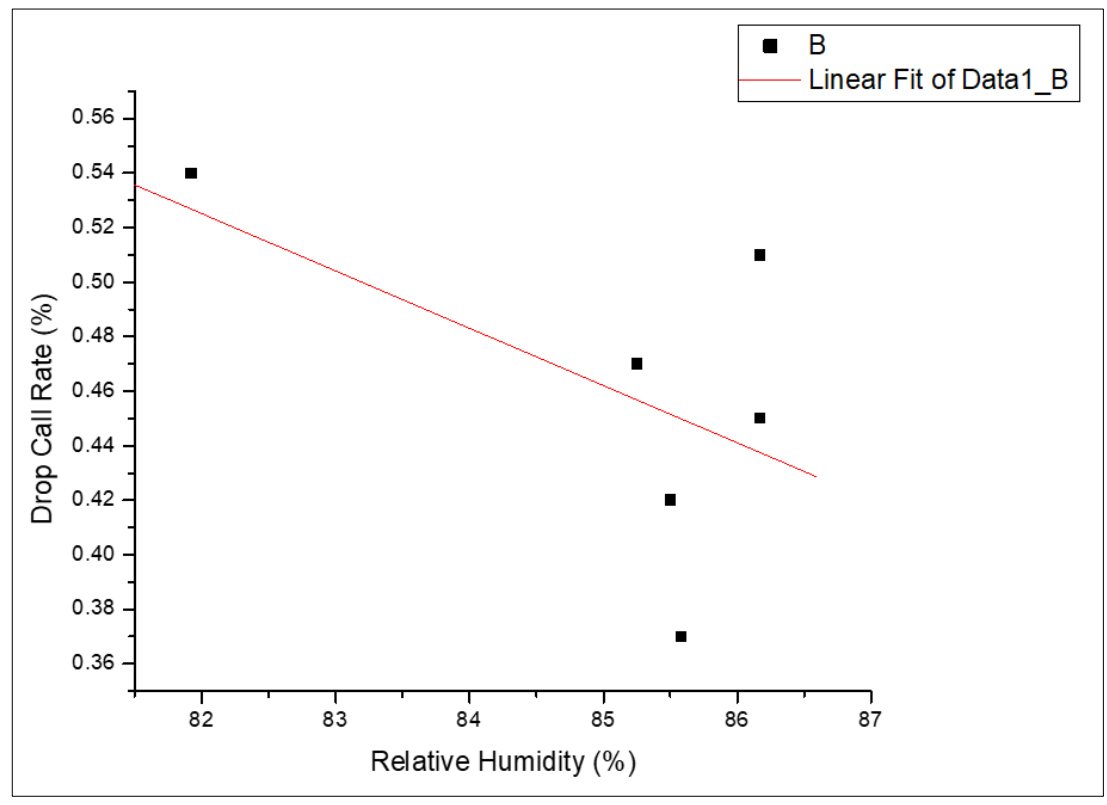

Figure 2 Graph of DCR against Relative Humidity for Airtel Network 


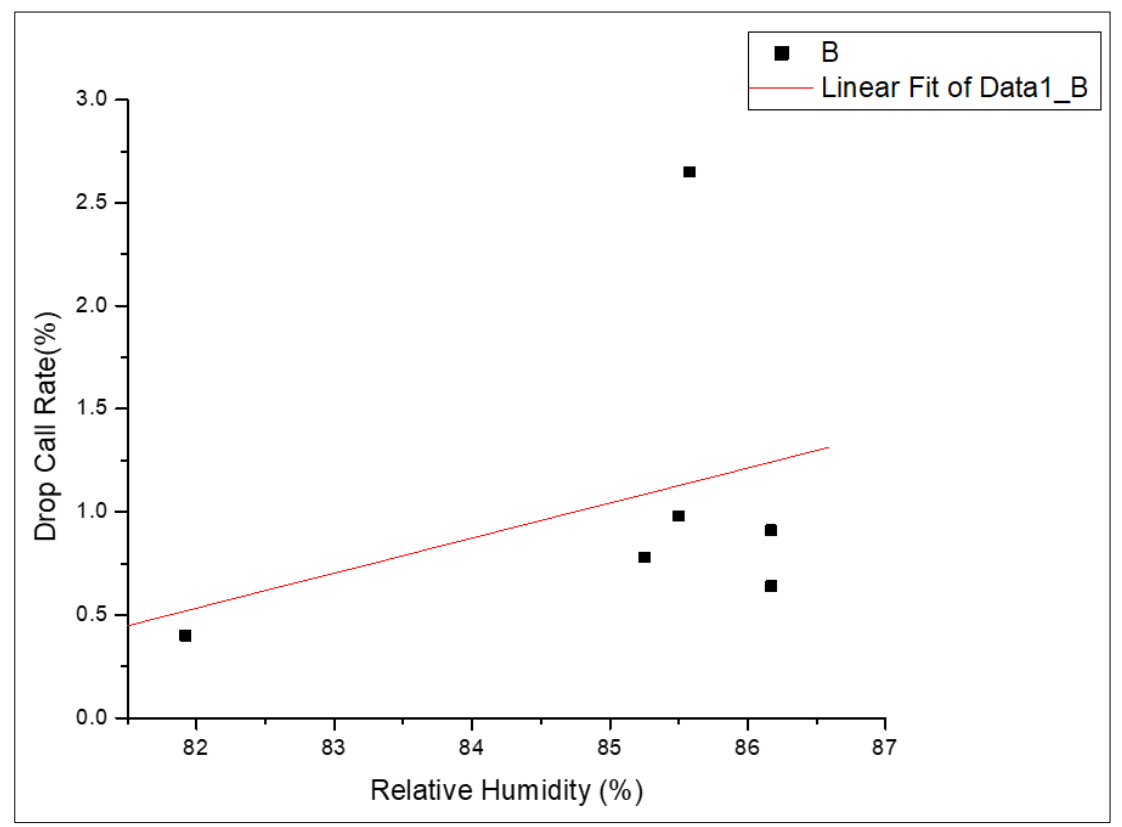

Figure 3 Graph of DCR against Relative Humidity for Globacom Network

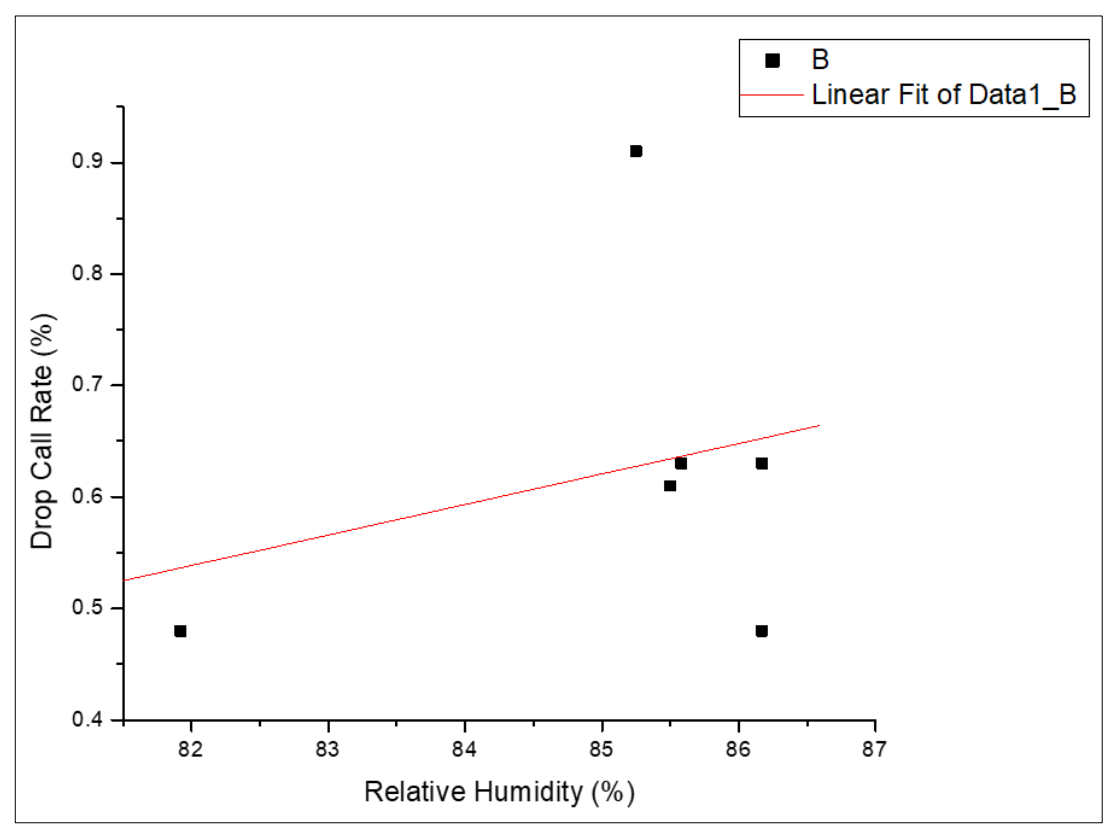

Figure 4 Graph of DCR against Relative Humidity for 9Mobile Network

\subsection{Effects of Wind Speed on Drop Calls}

In this section, figure 5 to 8 flaunt graphs of DCR against wind speed for MTN, Airtel, Globacom and 9mobile network respectively. For MTN network, a high negative correlation of 0.99 was obtained with regression equation $\mathrm{D}=0.02 \mathrm{~W}-$ 0.85 . A regression model $\mathrm{D}=0.01 \mathrm{~W}+0.55$ and a low negative correlation value of -0.13 was obtained for Airtel network. For Globacom network, a low positive correlation of 0.10 was obtained with a derived regression equation $\mathrm{D}=0.02 \mathrm{~W}+$ 0.18 . For 9 mobile network, a regression model $\mathrm{D}=0.03 \mathrm{~W}-0.99$ along with a very strong correlation value of 0.93 was obtained. In each case, D represents DCR while W represents the wind speed. 
Global Journal of Engineering and Technology Advances, 2022, 10(02), 083-093

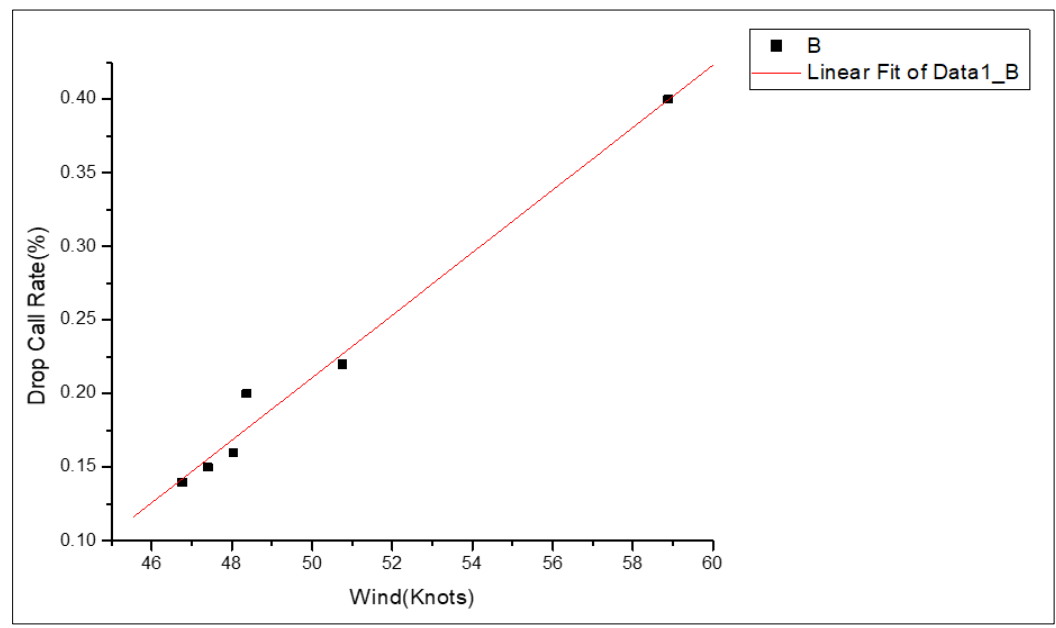

Figure 5 Graph of DCR against Wind Speed for MTN Network

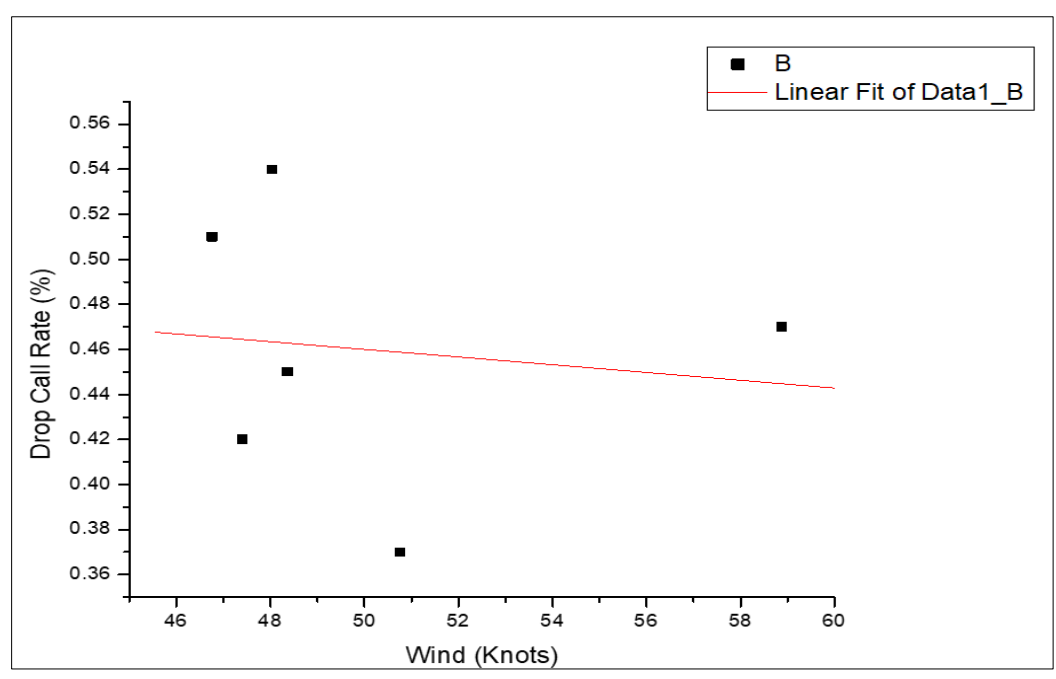

Figure 6 Graph of DCR against Wind Speed for Airtel Network

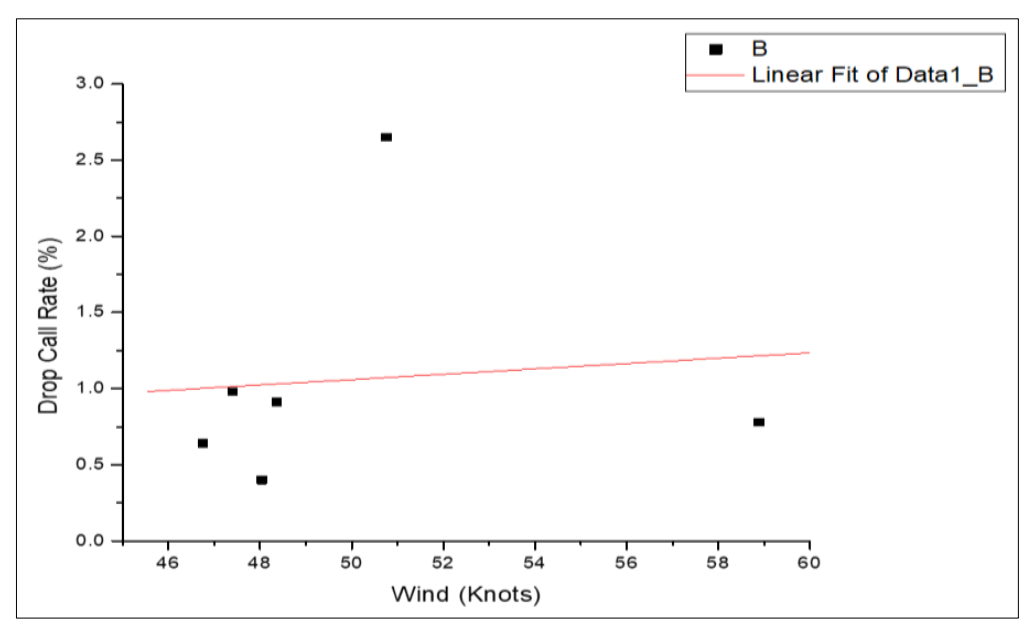

Figure 7 Graph of DCR against Wind Speed for Globacom Network 
Global Journal of Engineering and Technology Advances, 2022, 10(02), 083-093

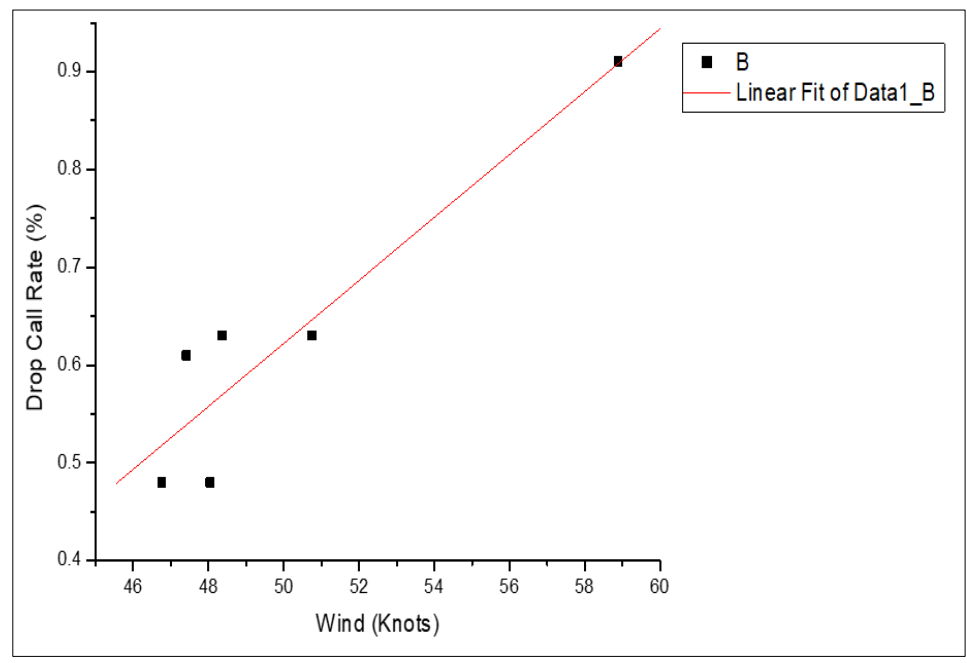

Figure 8 Graph of DCR against Wind Speed for 9mobile Network

\subsection{Effects of Rainfall on Drop Calls}

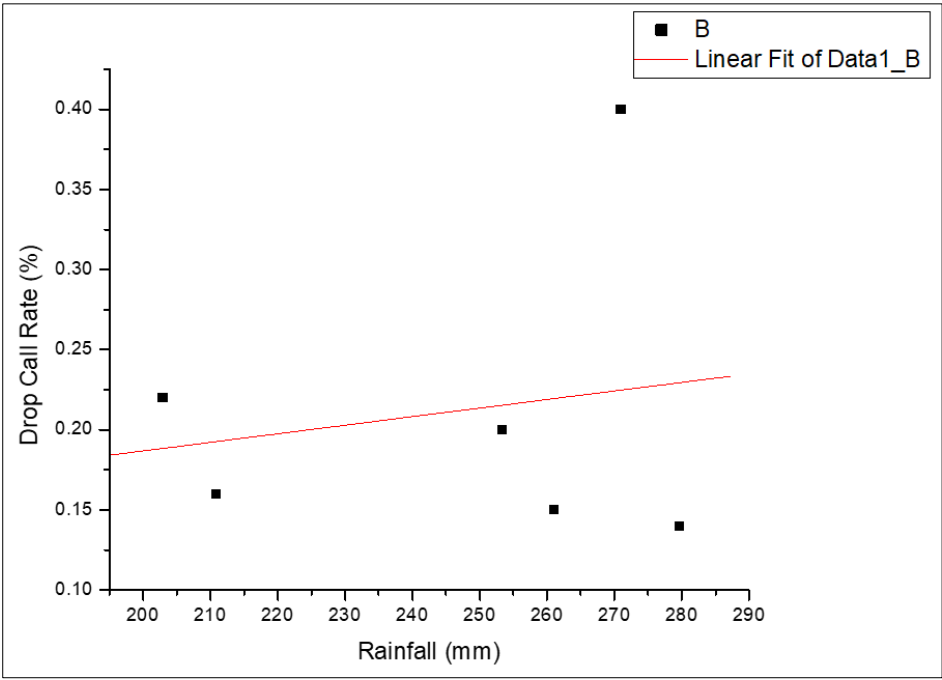

Figure 9 Graph of DCR against Rainfall for MTN Network

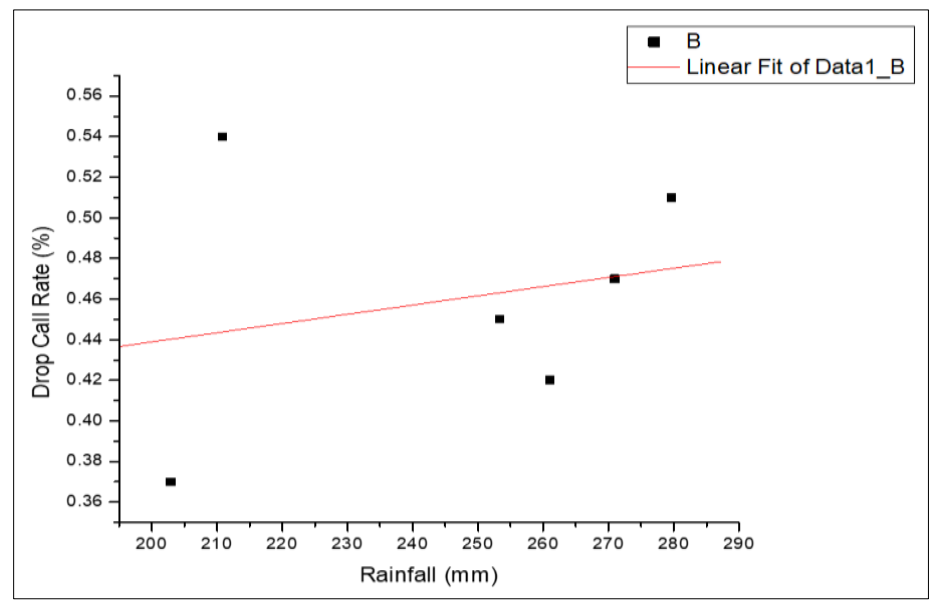

Figure 10 Graph of DCR against Rainfall for Airtel Network 


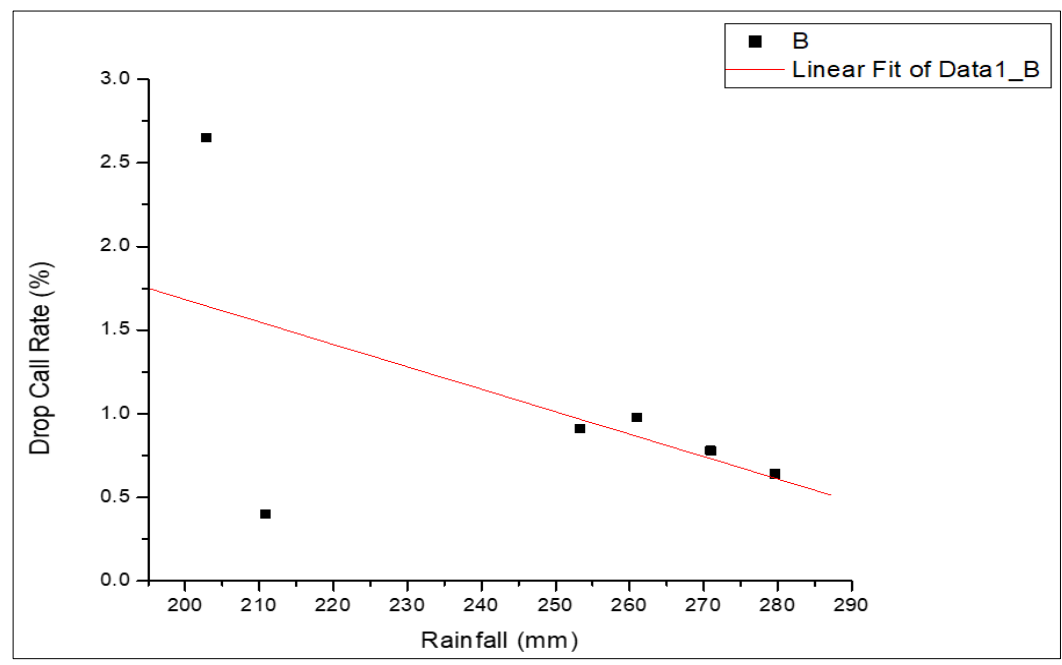

Figure 11 Graph of DCR against Rainfall for Globacom Network

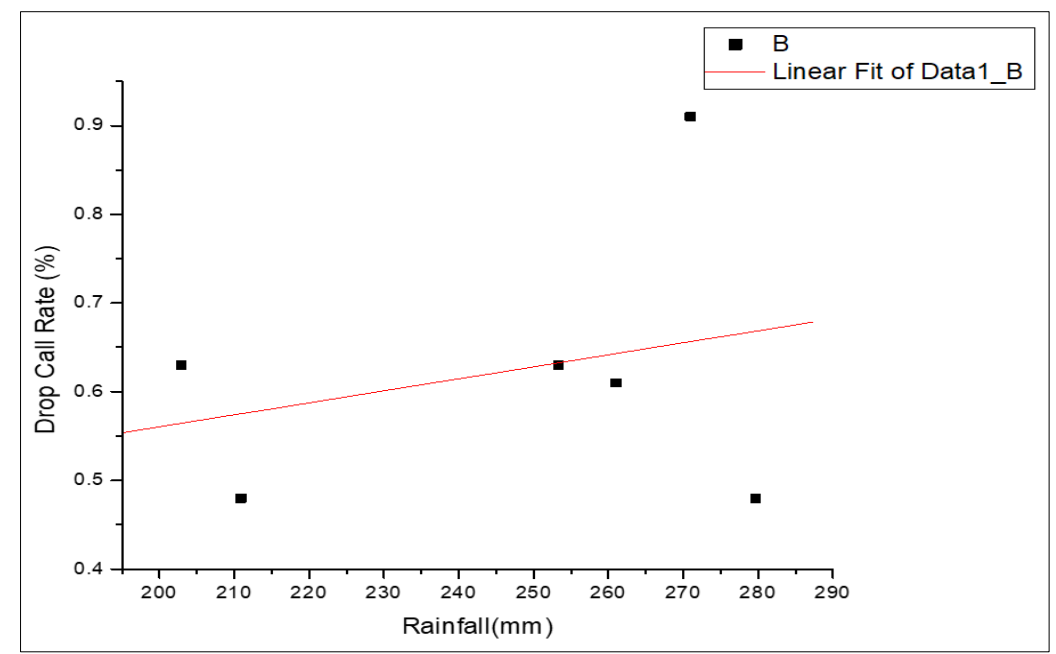

Figure 12 Graph of DCR against Rainfall for 9mobile Network

Here, figure 9 to 12 present graphs of DCR against rainfall for MTN, Airtel, Globacom and 9mobile network respectively. A weak positive correlation of 0.18 , a weak positive correlation of 0.24 , a moderately negative correlation of - 0.53 and a low positive correlation of 0.28 was obtained for MTN, Airtel, Globacom and 9mobile network, respectively. Furthermore, regression models were obtained for the four networks: $\mathrm{D}=0.01 \mathrm{RF}+0.08$ for MTN network, $\mathrm{D}=0.01 \mathrm{RF}$ +0.35 for Airtel network, $\mathrm{D}=-0.01 \mathrm{RF}+4.37$ for Globacom network and $\mathrm{D}=0.01 \mathrm{RF}+0.29$ for 9mobile network. Again, D represents DCR while RF represents rainfall.

\subsection{Effects of Temperature on Drop Calls}

Lastly, figures 13 to 16 unveil graphs of DCR against temperature for the four networks under study. A low negative correlation value of -0.22 was obtained for MTN network, a moderately negative correlation value of - 0.65 was realized for Airtel network, a highly positive correlation value of 0.91 was obtained for Globacom network and a low negative correlation of -0.24 was obtained for 9 mobile network. Again, regression equations $\mathrm{D}=-0.03 \mathrm{~T}+1.04, \mathrm{D}=-0.05 \mathrm{~T}+$ $1.99, \mathrm{D}=-0.88 \mathrm{~T}-27.07$ and $\mathrm{D}=-0.04 \mathrm{~T}+2.04$ were obtained for MTN, Airtel, Globacom and 9mobile networks. Here, D stands for DCR while T represents temperature. 
Global Journal of Engineering and Technology Advances, 2022, 10(02), 083-093

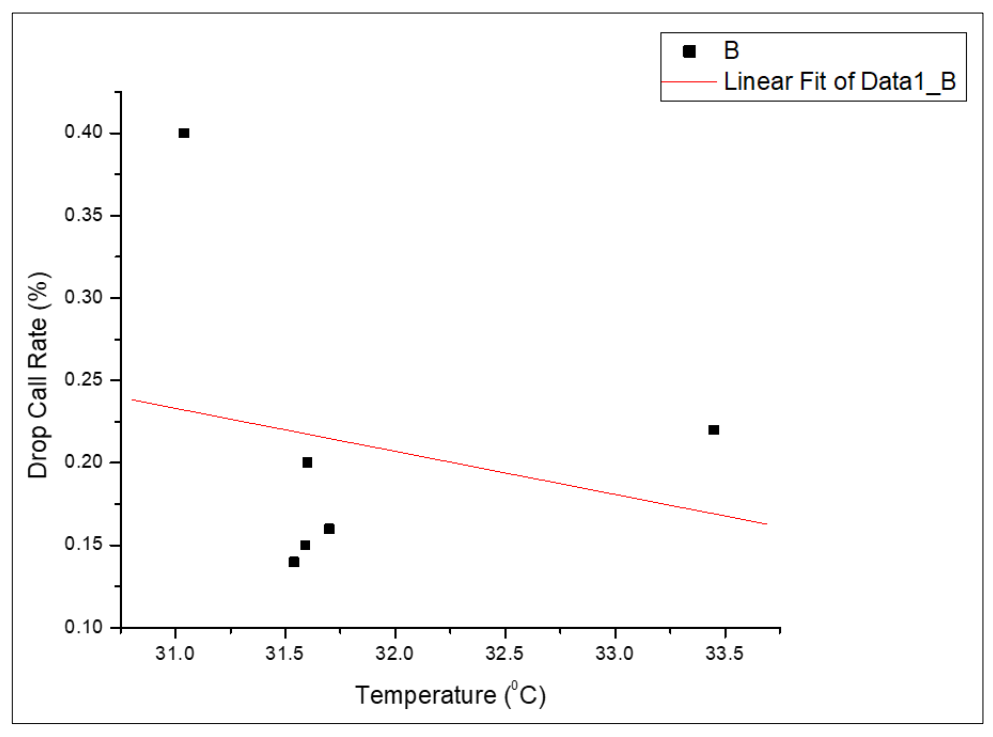

Figure 13 Graph of DCR against Temperature for MTN Network

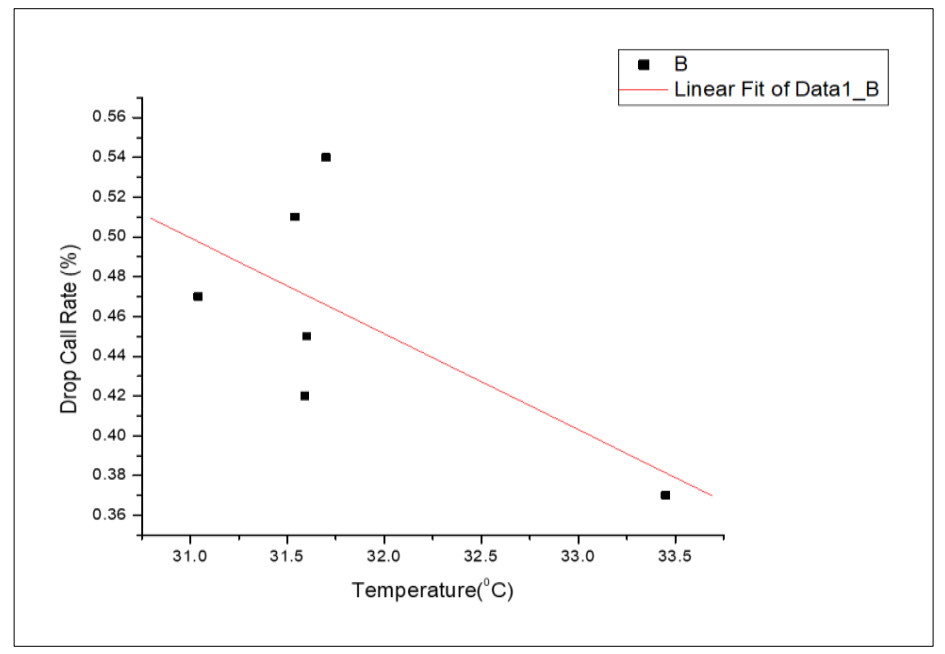

Figure 14 Graph of DCR against Temperature for Airtel Network

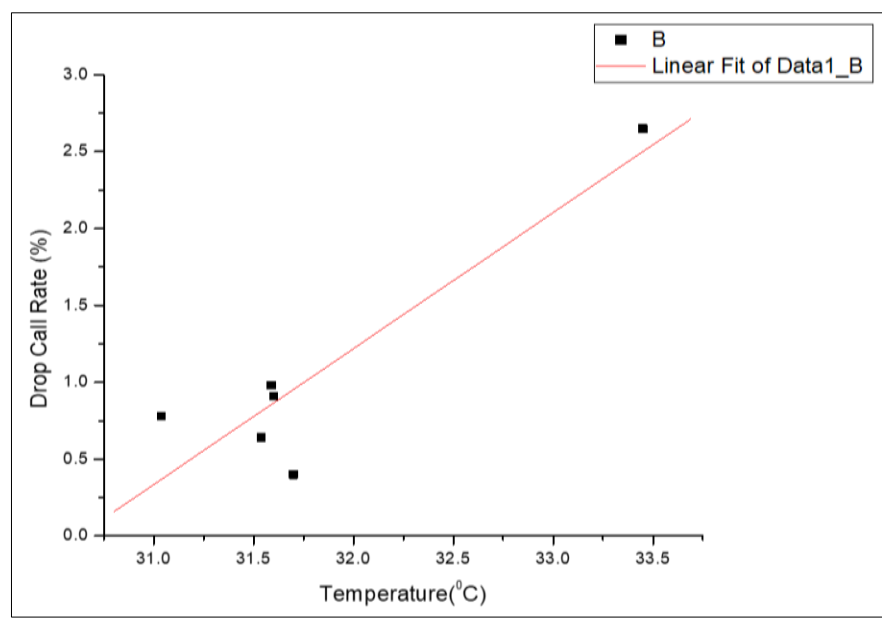

Figure 15 Graph of DCR against Temperature for Globacom Network 


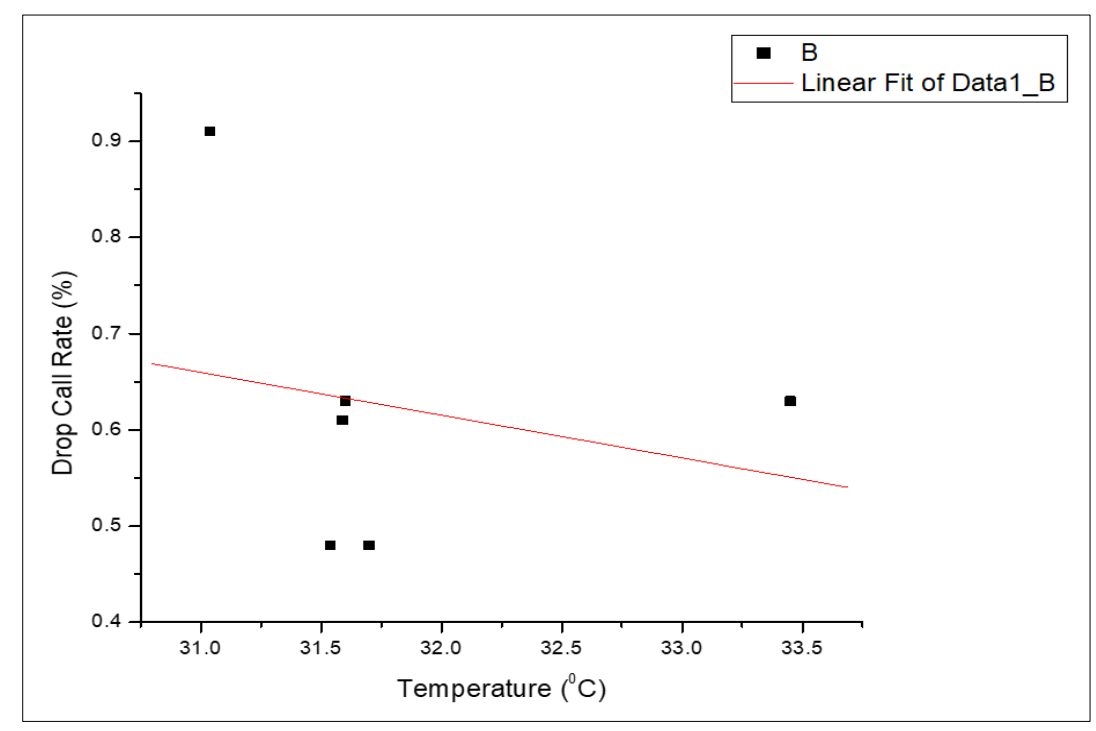

Figure 16 Graph of DCR against Temperature for 9mobile Network

\section{Conclusion}

The influence of tropospheric variables (relative humidity, wind speed, rainfall and temperature) on drop calls for four mobile networks operating in Cross River State have been studied. The drop calls of the four networks investigated varied with tropospheric variables in an irregular pattern. The results of this study will be useful to RF planners, NCC, the meteorologists and those in academics.

\section{Compliance with ethical standards}

\section{Acknowledgments}

Sincere thanks to the Nigerian Meteorological Agency (NiMet) and the Nigerian Communication Commission (NCC) for the meteorological and drop calls data that was used to carry out this study.

\section{Disclosure of conflict of interest}

There was no conflict of interest in this study.

\section{References}

[1] Akanbasiam JA, Ngala DK. The study of quality of service on a major network operator in Ghana. IOSR Journal of Electronics and Communication Engineering. 2017; 12(4): 21-25.

[2] Abdulkareem HA, Tekanyi AMS, Adamu H, Abdu-Aguye UF, Almustapha MD, Abdullahi ZM, Kassim AY, Muhammad ZZ, Musa IK. Evaluation of a GSM network quality of service using handover success rate as performance matrices. Zaria journal of electrical engineering technology. 2020; 9(2): 63-72.

[3] Galadanci GSM, Abdullahi SB. Performance analysis of GSM networks in Kano metropolis of Nigeria. American Journal of Engineering Research. 2018; 7(5): 69-79.

[4] Ekah UJ, Iloke J. Performance Evaluation of Key Performance Indicators for UMTS Networks in Calabar, Nigeria. GSC Advanced Research and Reviews. 2022; 10(1): 47-52.

[5] Lawal BY, Ukhurebor KE, Adekoya MA, Aigbe, EE. Quality of service and performance analysis of a GSM network in Eagle Square, Abuja and its environs, Nigeria. International Journal of Scientific and Engineering Research. 2016; 7(8): 1992-1999.

[6] Ekah UJ, Emeruwa C. Guaging of key performance indicators for 2G mobile networks in Calabar, Nigeria. World Journal of Advanced Research and Reviews. 2021; 12(2): 157-163. 
[7] Adelakun AO, Lawal BY, Adekoya MA, Ukhurebo KE. Chaotic assessment of the key performance indicators for a GSM Network congestion in an election period in Nigeria. Nigeria Journal of Pure \& Applied Physics. 2020; 9(1): 28-33.

[8] Ozovehe A, Usman AU. Performance analysis of GSM networks in Minna metropolis of Nigeria. Nigerian Journal of Technology. 2015; 34(2): 359-367.

[9] Seybold JS. Introduction to RF Propagation. John Wiley \& Sons, Inc. 2005.

[10] Chima AI, Onyia AI, Udeghe SU. The effects of atmospheric temperature and wind speed on UHF radio signal; a case Study of ESUT community and its environs in Enugu State. IOSR Journal of Applied Physics. 2018; 10(2): 8390.

[11] Eli-Chukwu NC, Onoh GN. Experimental Study of the Impact of Weather Conditions on Wide Code Division Multiple Access signals in Nigeria. Engineering, Technology and Applied Science Research. 2019; 9(2): 39984001.

[12] Sireesha BV, Varadarajan S, Vivek, Naresh. Increasing of Call Success Rate in GSM Service Area using RF Optimization. International Journal of Engineering Research and Applications. 2011; 1(4): 1479-1485.

[13] Gunashekar SD, Siddle DR, Warrington EM. Transhorizon radio wave propagation due to evaporation ducting: the effect of tropospheric weather conditions on VHF and UHF radio paths over the sea. Resonance. 2006; 11(1): 51-62.

[14] Luomala J, Hakala I. Effects of temperature and humidity on radio signal strength in outdoor wireless sensor networks. Proceedings of the Federated Conference on Computer Science and Information Systems. 2015; 5(4): 1247-1255.

[15] Ekah UJ, Adeniran AO, Shogo OE. Spatial Distribution of Frequecncy Modulated Signals in Uyo, Nigeria. World Journal of Advanced Engineering Technology and Sciences. 2022; 5(1): 39-46.

[16] Ekah UJ, Emeruwa C. A comparative assessment of GSM and UMTS Networks. World Journal of Advanced Research and Reviews. 2022; 13(1): 187-196.

[17] Emeruwa C, Ekah UJ. Pathloss model evaluation for long term evolution in Owerri. International Journal of Innovative Science and Research Technology. 2018; 3(11): 491-496.

[18] Emeruwa C, Ekah UJ. Investigation of the variability of signal strength of wireless services in Umuahia, Eastern Nigeria. IOSR Journal of applied physics. June 2018; 10(3): 1-17.

[19] Sharma A, Jan P. Effects of rain on radio propagation in GSM. International Journal of Advanced Engineering and Applications. 2010; 2(1): 13-16.

[20] Shalangwa DA, Abdulrazak A, Jerome G. Influence of atmospheric parameters on Global System for Mobile Communication (GSM) outgoing calls quality in Mubi, Adamawa State, Nigeria. Journal of Mobile Communications. 2009; 3: 56-58.

[21] Suleman KO, Bello IT, Tijani LO, Ogunbode AO, Olayiwola WA. Effect of temperature and ground water on VHF radio wave propagation in tropical climate. International Journal of Scientific and Engineering Research. 2017; 8(2): 1391-1396.

[22] Segun AA, Olusoge AM, Kofoworola AH. Influence of Air Temperature, Relative Humidity and Atmospheric Moisture on UHF Radio Propagation in South Western Nigeria. International Journal of Science and Research. 2015; 4(8): 588-592.

[23] Dajab DD. Perspectives on the effects of harmattan on radio frequency waves. Journal of Applied Sciences Research. 2006; 2: 1014-1018.

[24] Abuhdima EM, Saleh, MI. Effect of sand and dust storms on GSM coverage signal in southern Libya. International Conference on Electronic Devices, Systems and Applications, Kuala Lumpur, Malaysia. 2010; 1-268.

[25] Ekejiuba CO, Adebayo AA, Adeoye OS. Assessment of GSM Network Failures, Quality of Service Evaluation and its Impacts on E-Learning. International Journal of Scientific and Applied Science. 2015; 1(5): 119-123.

[26] Maiti M, Ajay KD, Karmakar PK. Effect of climatological parameters on propagation delay through the atmosphere. The Pacific Journal of Science and Technology. 2009; 10(2): 14- 20. 
[27] Mendes VB, Collins P, Langley RB. The effects of propagation delay errors in airborne GPS precision positioning. 8th International Technical meeting of the Satellite Division of the Institute of Navigation held at Palm Springs from 12th-15th September 1995; 1-1689.

[28] Umar R, Sulan SS, Azlan AW, Ibrahim ZA, Mokhtar WZAW, Sabri NH. Radio frequency interference. The study of rain effect on radio signal attenuation. Malaysian Journal of Analytical Sciences. 2015; 19(5): 1093-1098.

[29] Osahenvenwem OA, Omatahunde BE. Impacts of Weather and Environmental Conditions on Mobile Communication Signal. Journal of Advances in Science and Engineering. 2018; 1(1): 33-38.

[30] Onuu, MU, Adeosin A. Investigation of propagation characteristics of UHF waves in Akwalbom State, Nigeria. Indian Journal of Radio and Space Physics. 2008; 37: 197-203.

[31] Eyo OE, Menkiti AI, Udo SO. Microwave Signal attenuation in harmattan weather along Calabar-Akampa line-ofsight link. Turkish Journal of Physics. 2003; 27: 153-160.

[32] Dohnalek P, Dvorsky M, Gajdos P, Michaelek L, Sebesta R, Voznak M. A signal strength fluctuating prediction model based on the random forest algorithm. Electronika IR Elektrotechnika. 2014; 20(5): 123-126.

[33] Iloke J, Utoda R, Ekah U. Evaluation of Radio Wave Propagation through Foliage in Parts of Calabar, Nigeria. International Journal of Scientific \& Engineering Research. 2018; 9(11): 244-249.

[34] Ewona I, Ekah U. Influence of Tropospheric Variables on Signal Strengths of Mobile Networks in Calabar, Nigeria. Journal of Scientific and Engineering Research. 2021; 8(9): 137-145.

[35] Ayantunji BG, Chima AI, Ogbonna RC. The Impact of Atmospheric Temperature and Wind Speed on Satellite Signal at Ku Band. International Journal of Scientific \& Engineering Research. 2018; 9(2): 764-775.

[36] Sebin S, Renimol S, Abhiram D, Premlet B. Effect of rainfall on cellular signal strength: A study on the variation of RSSI at user end of smartphone during rainfall. 2017 IEEE Region 10 Symposium (TENSYMP), 14-16 July 2017, Cochin, India.

[37] Alor MO, Abonyi DO, Okafor PU. Determination of the Effect of Rain on Cellular Signal Receptions. International Journal of Advances in Engineering and Management. 2015; 2(3): 96-101.

[38] Voznak M, Rozhan J. Influence of Atmospheric Parameters on Speech Quality in GSM/UTMS. International Journal of Mathematical Models and Methods in Applied Sciences. 2012; 6(4): 575-582.

[39] Shoewu O, Akinyemi LA, Edeko FO. Effects of Climatic Change on GSM Signal in Lagos Metropolitan Terrain. Review of Environment and Earth Sciences. 2014; 1(2): 46-61.

[40] Amir G, Ghofrane F, Faouzi D, Maher BJ. Impacts of Temperature and Humidity variations on RSSI in indoor Wireless Sensor Networks. Procedia Computer Science. 2018; 126: 1072-1081.

[41] Sharifah NA, Syed Z, nor HS, Roslan U, Zainol AI. Radio Frequency Interference on Nearby Radio Astronomical Lines: Relationship between Wind Speed and Radio Signal Strength Measured at East Coast of Peninsular Malaysia. Sains Malaysiana. 2019; 48(1): 183-189.

[42] Akpan CS, Onuu MU. (2021). Design and Construction of a weather instrument and its use in measurements to determine the effects of some weather parameters on GSM Signal strength. Advances in Applied Sciences. 2021; 6(4): 142-154.

[43] Ajayi OT, Onidare SO, Ayeni AA, Adebowale QR, Yusuf SO, Ogundele A. Performance evaluation of GSM and WCDMA networks: a case study of the University of Ilorin. 2021; 13(1): 87-106.

[44] Obi E, Ekah U, Ewona I. Real-time assessment of cellular network signal strengths in Calabar. International Journal of Engineering Sciences \& Research Technology. 2021; 10(7): 47-57. 